\title{
Pyridoxine Afhankelijke Epilepsie
}

Pyridoxine afhankelijke epilepsie is een zeer zeldzame vorm van epilepsie die zich openbaart in de eerste uren na de geboorte. Als een pasgeborene met aanhoudende epilepsie ondanks toediening van meerdere anti-epileptica reageert op pyridoxine is dat bij uitstek een voorbeeld van succesvolle precisiegeneeskunde. Deze bijdrage beschrijft een Nederlands onderzoek ${ }^{1}$ naar de zeldzame stofwisselingsziekte die deze epilepsievorm veroorzaakt.

Epilepsie bij pasgeborenen is een ernstige aandoening die ongeveer 300 keer per jaar gediagnostiseerd wordt in Nederland. Nederland heeft een uitstekend protocol voor de behandeling van pasgeborenen met epilepsie. Meestal wordt epilepsie bij pasgeborenen veroorzaakt door zuurstoftekort bij de geboorte, een hersenbloeding rond de geboorte, of een meningitis. Heel soms (vijftien keer per jaar in Nederland) wordt de epilepsie veroorzaakt door een stofwisselingsziekte, waarvan er ruim 600 verschillende zijn. Eén van deze zeldzame stofwisselingsziekten die epilepsie bij pasgeborenen kan veroorzaken, is pyridoxine afhankelijke epilepsie, een vorm van epilepsie die niet reageert op de gewone anti-epileptica, maar wel reageert op een stevige dosering pyridoxine (vitamine B6). Pyridoxine afhankelijke epilepsie is voor het eerst beschreven in 1954 door Hunt. De oorzaak bleef jaren een raadsel, tot in 2006 werd ontdekt dat pyridoxine afhankelijke epilepsie veroorzaakt wordt door een stoornis in de afbraak van het aminozuur lysine; een stofwisselingsziekte (Mills et al., 2006).

\section{Epidemiologie}

Het onderzoek naar de zeldzame stofwisselingsziekte startte in 2005 door te analyseren hoe vaak pyridoxine afhankelijke epilepsie voorkomt in Nederland. Dankzij de medewerking van alle collega's kinderartsen, neonatologen, kinderneurologen en ouders in Nederland, werden er in 2005 tien kinderen met pyridoxine afhankelijke epilepsie opgespoord (Been et al., 2005). Inmiddels zijn er in Nederland 30 kinderen met deze diagnose. Uit onderzoek bleek dat pyridoxine afhankelijke epilepsie ongeveer eenmaal per jaar, bij één op de 200.000 pasgeborenen voorkomt in Nederland. In vergelijking met andere landen in de wereld is dit relatief vaak; bijvoorbeeld in Engeland komt het slechts bij één op de 800.000 pasgeborenen voor.
In Nederland heeft $85 \%$ van de Nederlandse patiënten met pyridoxine afhankelijke epilepsie dezelfde mutatie in het ALDH7A1-gen, c.1279G $>$ C, p.Glu427Gln (historische naam p.Glu399Gln). Deze specifieke mutatie wordt in andere landen bij slechts io tot 30\% van de pyridoxine afhankelijke epilepsiepatiënten gevonden. Een dergelijk hoog percentage in Nederland berust op een zogenaamd founder effect. Dat wil zeggen dat het waarschijnlijk is dat de Nederlandse patiënten eeuwen geleden één verre gemeenschappelijke onbekende voorouder hebben.

\section{Pathogenese en diagnostiek}

De afbraak van het aminozuur lysine verloopt in stappen door enzymen. Bij pyridoxine afhankelijke epilepsie ontbreekt het enzym alfa-Amino Adipine SemiAldehyde $(\alpha$-AASA) dehydrogenase. Daardoor stapelt het tussenproduct $\alpha$-AASA, die zich bindt aan pyridoxine zich op, door deze binding ontstaat een ernstig tekort aan pyridoxine. Dit ernstige tekort aan pyridoxine veroorzaakt epilepsie. De meeste patiënten met pyridoxine afhankelijke epilepsie presenteren zich met epilepsie kort na de geboorte; maar ongeveer eenvierde van de patiënten heeft een atypische presentatie, dat wil zeggen het eerste symptoom is niet epilepsie, of de epilepsie start pas na de derde levensmaand of, wat ook mogelijk is, de epilepsie reageert aanvankelijk wel op een 'gewoon' anti-epilepticum (Coughlin et al., 202I).

Het metaboliet $\alpha$-AASA in de urine is heel specifiek om pyridoxine afhankelijke epilepsie aan te tonen. Voorwaarde is dat de urine goed bewaard wordt in een diepvries, want bij kamertemperatuur verdwijnt dit $\alpha$-AASA geleidelijk. Helaas worden hielprikkaartjes in Nederland maximaal vijf jaar bewaard op kamertemperatuur. Dit bemoeilijkt eventuele screening bij de geboorte via het stofje $\alpha$-AASA

${ }^{1}$ Een consortium vanuit het Maxima MC Veldhoven samen met het Radboud ziekenhuis (Prof van Karnebeek), in dit consortium - waar de deur open staat - participeren het UMCG, het AUMC, het UMCU en het Erasmus Ziekenhuis. 
bemoeilijkt. Gelukkig is in het Radboud recent een nieuwe methode ontwikkeld die hielprik screening technisch mogelijk maakt (Engelke et al., 202I).

Uit Nederlands onderzoek is gebleken dat het EEG niet het optimale onderzoek is om met voldoende zekerheid pyridoxine afhankelijke epilepsie aan te tonen of uit te sluiten. De reactie die te zien is in het EEG kan verdacht zijn en passen bij pyridoxine afhankelijke epilepsie, maar de veranderingen die te zien zijn, zijn niet specifiek genoeg. Daarom moet de diagnose worden gesteld met urine-onderzoek van $\alpha$-AASA, of DNA-onderzoek. En pyridoxine moet toegediend blijven worden totdat deze uitslag bekend is.

\section{Prognose}

De individuele prognose kan slechts beperkt worden voorspeld. Niet voorspellend zijn de mutatie, het EEG, de MRI of de pyridoxine dosering. Helaas is de prognose van kinderen met pyridoxine afhankelijke epilepsie niet goed, $75 \%$ van de kinderen loopt pas na het tweede levensjaar, het gemiddeld IQ is 72, drievierde van de kinderen volgt speciaal onderwijs of krijgt extra ondersteuning in het reguliere onderwijs en een kwart van de kinderen krijgt naast pyridoxine ook aanvullende anti-epileptica (Bok et al., 20I2). Ondanks het feit dat de laatste jaren in Nederland vaak snel de diagnose wordt gesteld en de behandeling met pyridoxine vaak vroeg is gestart is deze prognose de laatste jaren niet veranderd. Gelukkig is heel recent in een kleine groep kinderen na een follow-up van gemiddeld twee jaar gezien dat het vroeg starten van een dieet met lysinerestrictie voor de derde levensmaand de uitkomst niet normaliseert maar wel significant verbetert (Coughlin CR 2nd, submitted).

\section{Conclusie en toekomstig onderzoek}

Verdere studies zijn nodig om de prognose van kinderen met pyridoxine afhankelijke epilepsie te verbeteren. Deze studies zouden zich moeten richten op de verdere ontrafeling van het ziektemechanisme, de effecten van een dieet met beperking van (lysine) eiwit, arginine suppletie en op de hoogte van de dagdosering pyridoxine B6. Momenteel vindt dit onderzoek plaats vanuit het expertisecentrum pyridoxine afhankelijke epilepsie.

\section{Referenties.}

Been JV, Bok LA, Andriessen P, et al. (2005) Epidemiology of pyridoxine dependent seizures in the Netherlands. Arch Dis Child 90: 1293-6.

Bok LA, Halbertsma FJ, Houterman S, et al. (20I2) Long-term outcome in pyridoxine-dependent epilepsy. Dev Med Child Neurol. 54(9):849-54

Coughlin CR 2nd, Tseng LA, Bok LA, et al. (202I) Consensus guidelines for the diagnosis and management of pyridoxine-dependent epilepsy due to alphaaminoadipic semialdehyde dehydrogenase deficiency.

J Inherit Metab Dis. 44(I):I78-I92

Coughlin CR 2nd, et al (submitted) Lysine reduction therapies and cognitive outcomes in patients with PDE-ALDH7AI.

Engelke UF, Bok LA, van Karnebeek CD, et al. (202I) Untargeted metabolomics and infrared ion spectroscopy identify biomarkers for pyridoxine-dependent epilepsy. J Clin Invest 2;I3I(I5)

Mills PB, Struys E, Jakobs C, et al. (2006) Mutations in antiquitin in individuals with pyridoxine-dependent seizures. Nat Med I2: 307-9. 